\title{
Implementasi Program Keluarga Harapan Dalam Pengentasan Kemiskinan Di Kelurahan Purnama Kecamatan Dumai Barat
}

\author{
Liberti $^{* 1}$, Febri Yuliani ${ }^{2}$ \\ ${ }^{12}$ Fakultas Ilmu Sosial dan Ilmu Politik, Universitas Riau \\ Korespondensi : libertiibet1102@gmail.com
}

\begin{abstract}
Abstrak
Program Keluarga Harapan ( $\mathrm{PKH}$ ) adalah program yang memberikan bantuan tunai bersyarat kepada Rumah Tangga Sangat Miskin (RTSM) yang telah ditetapkan sebagai peserta PKH. peserta PKH diwajibkan memenuhi persyaratan dan komitmen yang terkait dengan upaya peningkatan kualitas sumber daya manusia (SDM), yaitu pendidikan dan kesehatan. Penilitian ini bertujuan Untuk menganalisis implementasi Kebijakan PKH Di Kecamatan Dumai Barat dan mengidentifikasi faktor penghambat dalam implementasi PKH di Kecamatan Dumai Barat. Penelitian ini merupakan penelitian kualitatif dimana teknik yang digunakan dalam pengumpulan data menggunakan teknik wawancara, observasi dan dokumentasi. Sumber data dari penelitian ini terdapat empat orang yaitu Kepala Dinas Sosial, Pendamping Program Keluarga Harapan kecamatan, PSM (Pekerja Sosial Masyrakat), Penerima bantuan Program Keluarga Harapan. Pemilihan sumber data pada penelitian ini menggunakan purposive sampling. Adapun yang menjadi hasil dari penelitian ini adalah implementasi Program Keluarga Harapan (PKH) Kecamatan Dumai Barat belum maksimal dan masih banyak kekurangan yang perlu diperbaiki. Hal ini terlihat dari kelompok sasaran yang belum tepat; jumlah pelaksana yang terbatas baik dari segi kuantitas maupun kualitas (skill) sehingga belum bisa dikatakan maksimal. Penelitian ini dijawab menggunakan teori Grindle, yaitu Content Of Polish serta kendala yang ditemukan yaitu : Minim anggaran dari pemerintah, Sumber daya masyarakat yang masih perlu penyesuaian jumlahnya untuk mendukung validitas data penerima PKH
\end{abstract}

Kata Kunci : Implementasi, Pengentasan Kemiskinan, PKH

\begin{abstract}
The Family Hope Program (PKH) is a program that provides conditional cash assistance to Very Poor Households (RTSM) who have been designated as PKH participants. PKH participants are required to meet the requirements and commitments related to efforts to improve the quality of human resources (HR), namely education and health. This study aims to analyze the implementation of PKH policies in West Dumai District and identify the inhibiting factors in PKH implementation in West Dumai District. This research is a qualitative research in which the techniques used in data collection using interview techniques, observation and documentation. There are four sources of data from this study, namely the Head of the Social Service, the subdistrict Family Hope Program Facilitator, PSM (Community Social Worker), Recipients of the Family Hope Program. The selection of data sources in this study used purposive sampling. The result of this research is that the implementation of the Family Hope Program (PKH) in West Dumai District has not been maximized and there are still many shortcomings that need to be fixed. This can be seen from the target group that is not yet right; the number of implementers is limited both in terms of quantity and quality (skills) so that it cannot be said to be maximal. This research was answered using Grindle's theory, namely Content Of Polish and the obstacles found were: Minimum budget from the government, Community resources that still needed to be adjusted in number to support the validity of $P K H$ recipient data.
\end{abstract}

Keywords: Implementation, Poverty Alleviation, PKH

P-ISSN 1693-3516 | E-ISSN 2528-7575 224 


\section{PENDAHULUAN}

Program Keluarga Harapan adalah sebuah program perlindungan sosial yang memberikan bantuan tunai kepada Rumah Tangga Sangat Miskin (RTSM) berdasarkan persyaratan dan ketentuan yang telah ditetapkan. Pemeliharaan kesehatan ibu sedang mengandung pada keluarga sangat miskin sering tidak memadai sehingga menyebabkan buruknya kondisi kesehatan bayi yang dilahirkan atau bahkan kematian bayi. Adapun berbagai indikator dari Program Keluarga Harapan adalah di khususnya pada bidang pendidikan dan kesehatan. Rendahnya kondisi kesehatan suatu keluarga sangat miskin berdampak pada tidak optimalnya proses tumbuh kembang anak, terutama pada usia 0-5 tahun. Gizi kurang berdampak buruk pada produktivitas dan daya tahan tubuh seseorang sehingga menyebabkannya terperangkap dalam siklus kesehatan yang buruk.

Program Keluarga Harapan merupakan program lintas sektor, karena pelaksanaannya melibatkan berbagai sektor dan tingkatan pemerintahan, yaitu: Menko Kesra, Bappenas, Departemen Sosial, Departemen Kesehatan, Departemen Pendidikan Nasional, Departemen Agama, dan Departemen Komunikasi dan Informatika. Pelaksanaan Program Keluarga Harapan juga didukung oleh BPS untuk penyediaan data penerima dan PT Pos Indonesia untuk sistem manajemen informasi pembayaran serta tenaga ahli (pendamping) Program Keluarga Harapan di masyarakat. Program Keluarga Harapan bukan merupakan kelanjutan atau pengganti program bantuan langsung tunai (BLT) 2005/2006 sebagai kompensasi kenaikan Bahan bakar minyak, tapi untuk memberdayakan kaum ibu dari kalangan miskin agar mampu berusaha dan medorong anak tetap sehat dan bersekolah. Departemen Sosial dalam menjalankan suatu Program atau kebijakan yang dilakukan akan mengacu pada sebuah keputusan atau peraturan. Landasan Program Keluarga Harapan dalam pengentasan kemiskinan yaitu pada UU No 40 tahun 2004 tentang sistem jaminan sosial dan Undang-Undang Nomor 11 Tahun 2009 tentang Ketentuanketentuan Pokok Kesejahteraan Sosial.

Oleh karena itu pengentasan kemiskinan melalui PKH ini menjadi prioritas pemerintah Indonesia dan sekaligus menjadi program andalan sebagai upaya pemerintah untuk mengentaskan kemiskinan. Selanjutnya perlu koordinasi dan sinergisitas dan dukungan lintas kementerian seperti : Ketenagakerjaan, Pendidikan dan Kebudayaan, dan Kesehatan. Sehingga upaya pemerintah dalam rangka mengentaskan kemiskinan tersebut dapat segera diwujudkan (Cahyo Sasmito,2019:37). Pelaksanaan program bantuan ini khususnya dikelurahan purnama kecamatan Dumai Barat selain berlandaskan pada peraturan tersebut juga berlandaskan pada Surat keputusan Walikota Nomor 48 tahun 2016 tentang pembentukan tim koordinasi Program keluarga harapan Kelurahan Purnama dimana didalamnya terdapat koordnasi antar instansi pemerintah yang saling berhubungan dalam kaitannya pelaksanaan Program Kelarga Harapan.

Mengenai Implementasi Program Keluarga Harapan di Kelurahan Purnama Kecamatan Dumai Barat. Pertama, Tidak tepat sasaran yang menerima bantuan PKH untuk wilayah Kelurahan Purnama, sehingga sampai sekarang masih ada saja RTSM yang tidak layak sesuai persyaratan penerima bantuan PKH belum mendapatkan bantuan dan belum terdata dalam penerima bantuan PKH. Kedua, tidak tepat guna yang menerima bantuan program keluarga harapan, sehingga masih ada yang menggunakan dana tersebut untuk kebutuhan lain. Ketiga, masih rendahnya pengetahuan yang dimiliki sebagian pihak sekolah dalam memahami bantuan Program Keluarga Harapan bagi Rumah Tangga Sangat Miskin yang memiliki anak yang masih sekolah ditingkat SD atau SMP, karena ada sikap membedakan yang dilakukan sebagian pihak sekolah atas bantuan lainnya yang seharusnya diterima oleh anak dari kalangan miskin. Berdasarkan permasalahan diatas, maka peneliti tertarik untuk mengkaji lebih dalam mengenai Program Keluarga Harapan serta Implementasi Dikelurahan Purnama. 


\section{METODE}

Sesuai dengan pokok permasalahan diatas penelitian ini memiliki tujuan yang dicapai, diantaranya sebagai berikut : Untuk menganalisis implementasiKebijakan Program Keluarga Harapan Di Kecamatan Dumai Barat. Dan untuk mengidentifikasi faktor penghambat dalam implementasi Program Keluarga Harapan di Kecamatan Dumai Barat.

Jenis penelitian yang digunakan dalam penelitian kualitatif yang bersifat deskriptif yaitu untuk mengetahui atau menggambarkan kenyataan dari kejadian yang diteliti sehingga memudahkan penulis untuk mendapatkan data yang objektif dalam rangka mengetahui dan memahami Implementasi Program Keluarga Harapan (PKH) di Kecamatan Dumai Barat. Subjek dari penelitian ini dipilih dengan menggunakan teknik purposive sampling. Adapun informan penelitian yaitu :

1. Kepala Dinas Sosial

2. Pendamping Program Keluarga Harapan kecamatan

3. PSM (Pekerja Sosial Masyrakat)

4. Penerima bantuan Program Keluarga Harapan

Sampel adalah sebagian dari kuantitas populasi yang mencerminkan dari keseluruhan populasi tersebut. Dengan meneliti sebagian unit-unit dari populasi diharapkan dapat memperoleh hasil yang dapat memberikan gambaran sifat populasi bersangkutan.

\section{HASIL DAN PEMBAHASAN}

Pelaksanaan Program Keluarga Harapan ini memiliki hierarki sebagai alur tugas dan arahan dimana Pendamping PKH Kelurahan atau desa menempati posisi paling bawah yang mengawasi langsung tiap tiap KPM yang ada di tiap Kelurahan atau Desa. Pendamping PKH Kelurahan akan mendapatkan tugas sebagai pelaksana lapangan dalam pengasawan dan pengawasan lagsung tiap KPM. Selanjutnya pelaporan juga melalui kecamatan bidang kesejahteraan sosial, bantuan sosial, perlindungan sosial dan jaminan sosial dan di pimpin oleh masing masing camat.

Dalam penelitian ini peneliti akan membahas permasalahan ini dengan menganalisisnya menggunakan teori Grindle bahwa terdapat pengukuran keberhasilan dalam pelaksanaan progtan yang dilihat dari proses serta penentuannya sesuai dengan aksi program yang telah dilaksanakan dilapangan.

\section{Content Of Policy}

Content of polish atau isi kebijakan dari teori grindle menjelaskan bahwa implementasi kegiatan harus diikuti dengan kebijakan yang sudah diatur . sesuai dengan Peraturan Menteri Sosial nomor 1 tahun 2018 mengenai program keluarga harapan yakni terdapat 4 program utama yang memfokuskan keluarga menjadi keluarga harapan yaitu pencegahan stunting, graduasi Berdikari Sejahtera ,vilidasi di wilayah terdepan terluas dan terpencil dan disinergikan dengan program Keluarga Berencana.

\section{a. Interest Affected ( Kepentingan yang mempengaruhi )}

Dalam kepentingan yang mempengaruhi hal ini termasuk dalam implementasi kebijakan di mana pelaksanaannya terdapat banyak orang serta dilibatkan banyak kepentingan, hal ini Dinilai dari sejauh mana kepentingan ini akan berpengaruh terhadap implementasi pelaksanaan program yang dilakukan dan ingin diketahui oleh peneliti selanjutnya. keterlibatan pendamping dan KPM akan selalu berhubungan karena setiap masalah yang dimiliki oleh KPM akan di advokasi pertama oleh pendamping dan PSM. pendamping PKH di Kelurahan merupakan suatu alur pertama setelah yang bertanggung jawab untuk mengawasi kinerja dari KPM. kemudian koordinasi dari Kelurahan akan dilanjutkan ke Kecamatan, 
penentuan nama keluarga yang mendapatkan bantuan bukan ditentukan oleh pendamping kelurahan kecamatan ataupun dinas sosial di kabupaten atau kota namun nama ini sudah dikirim dari Kementerian melalui data-data yang cukup valid yang diberikan Sebelum rapat kerja antar daerah. tugas Dinas Sosial setingkat dengan kecamatan dan kelurahan adalah validasi dari data-data serta mengecek tanggungan menentukan kecocokan dari keluarga penerima yang layak ataupun tidak layak sehingga akan dikumpulkan dengan membentuk rapat musyawarah dalam penentuan penerima keluarga manfaat. koordinasi dari pendamping juga lewat melalui Arteri karena RT adalah Satuan terkecil dari pemerintahan di tiap-tiap daerah, ketua RT akan lebih memahami mengenai identitas kepala keluarga yang mereka Naungi dan juga masalah-masalah yang terdapat di daerah mereka sendiri yang harus diselesaikan sehingga mengetahui kelayakan dari penerima manfaat untuk beberapa tahun yang akan datang kecocokan ini juga akan mau validasi alamat serta kondisi rumah dan anggota kelua.

\section{b. Type of Benefits ( Tipe Manfaat )}

Tipe ini sebuah kebijakan harus bisa membuktikan bahwa setiap kebijakan yang diimplementasikan harus memiliki manfaat dan berguna untuk orang-orang dan serta lingkungan sekitarnya menunjukkan dampak yang positif serta memberikan pelajaran perbaikan untuk kedepannya pada kasus program keluarga harapan ini keluarga penerima manfaat yang menerima bantuan agar dapat mengimplementasikan program agar kebijakan yang dilaksanakan untuk menyelenggarakan PKH menjadi sukses. pelaksanaan program keluarga harapan di kecamatan Dumai barat sejauh ini telah memenuhi hak dan kewajiban bagi setiap petugas sesuai dengan tugas pokok dan fungsinya masing-masing serta telah dilaksanakan dengan baik, hal ini diiringi juga dengan rapat rutin serta musyawarah yang dilakukan sesama pelaksana PKH baik dalam tingkat kelurahan kecamatan dan kota sehingga permasalahan yang terjadi di beberapa kecamatan di Kota Dumai dapat dicegah dan di Cari solusinya. program keluarga harapan juga dibentuk berdasarkan kriteria-kriteria tertentu yang langsung di seleksi oleh Kementerian Sosial sehingga nama-nama petugas tersebut telah resmi mendapatkan Surat Keterangan atau SK dari Kementerian Sosial hari ini menjadikan setiap tanggung jawab dari pendamping program keluarga harapan harus membuat laporan kerjanya masing-masing dari laporan tersebut harus diselesaikan dengan baik dan dilaporkan secara rutin sehingga mereka bisa mendapatkan hak-hak mereka.

\section{c. Extent of Change Envision (Derajat Perubahan yang Ingin Dicapai)}

Mencapai tujuan dari perubahan zat implementasi kegiatan yang sedang dilaksanakan maka extent of Change and Vision merupakan batasan agar setiap kebijakan memiliki standar dan Skala yang lebih jelas untuk mencapai tujuannya. hal ini sebagaimana yang disebutkan dalam peraturan menteri pasal 2 mengenai tujuan diadakan program keluarga harapan agar tercapai perubahan setiap penerima manfaat adalah untuk membantu meningkatkan taraf hidup setiap penerima manfaat menjadi lebih baik lagi dari awal mereka sebagai rumah tangga sangat miskin Mbak itu dari segi pendidikan kesehatan serta kesejahteraan hidup bagi setiap anggota keluarganya. membentuk perilaku sesuai dengan keluarga harapan serta menjadikan keluarga rumah tangga sangat miskin menjadi lebih Mandiri lagi.

\section{d. Site of Decision Making (Letak Pengambilan Keputusan)}

keputusan tersebut berhak diambil oleh orang-orang Yang paham akan pelaksanaan kegiatan ini dan jika terjadi kekurangan maka harus dilakukan perbaikan untuk kedepannya. hierarki dari peraturan haruslah tetap diperhatikan karena kita memiliki pimpinan-pimpinan dari orang yang menyelenggarakan dan menyusun program tersebut. bagian tertinggi dari pelaksanaan program ini yakni langsung diarahkan oleh Kementerian sosial yang akan memberikan arahan kepada setiap kabupaten kota di Indonesia yakni a langsung Kepala Dinas Sosial. nantinya setiap dinas akan mendisposisikan tugasnya kepada bagian kesejahteraan dan penanggulangan bantuan masyarakat miskin, penentuan kebijakan ini bukan hanya 
diambil oleh satu orang saja namun juga melalui musyawarah dan mufakat atas diskusi-diskusi khusus kepada orang-orang yang memahami tujuan program dan sudah mendalami sesuai dengan bidangnya masing-masing. nantinya Surat keputusan ini akan diarahkan kepada Kecamatan serta Kelurahan dan akan didiskusikan kepada elemen terendah yaitu PRT yang memang paling paham dengan kondisi masyarakat mereka.

\section{e. Resources Committed (Sumber-Sumber Daya yang Digunakan)}

Setiap kebijakan yang dibuat terdapat tujuan yang telah ditentukan dan menjadi landasan dalam mengimplementasikan kebijakan tersebut. Namun, bukan bearti faktor tersebut menjadi tolak ukur utama dalam menentukan indikator kesuksesan kebijakan yang telah dilaksakan. Salah satu faktor lain yang juga sangat penting harus di pertimbangkan adalah Sumber daya yang digunakan dan dimanfaatkan agak bisa menunjang pelaksanaan tujuan yang ingin dicapai. Hal ini berpengaruh juga tengan ketersediaan sumber daya yang ada, beberapa sumber daya tersebut termasuk sumber daya waktu, finansial dan manusia, beberapa hal tersebut menjadi pendukung utama agak program kebijalan yang dilaksakan dapat dimaksimalkan sebaik mungkin.

\section{f. Power, Interest, and Strategy of Actor Involved (Kekuasaan, Kepentingan-Kepentingan, dan Strategi dari Aktor yang Terlibat)}

Pentingnya memperhatikan kekuasaan oleh beberapa orang atau kelompok yang akan membahas mengenai subjek kebijakan karena kalau ini pasti memiliki keuntungan dari masing-masing pihak baik terdapat dalam satu pihak maupun banyak pihak lainnya dan hal ini akan berlangsung dari kebijakan tersebut sendiri maka tidak heran efektivitas dari suatu kebijakan itu tergantung juga orang yang melaksanakan program tersebut. pengaruh dari pihak internal eksternal akan mendukung penuh implementasi dari subjek kebijakan yang ingin dicapai.

\section{g. Institution and Regime Characteristic (Karakteristik lembaga dan rezim yang sedang berkuasa)}

Nilai kepatuhan dan tidak kepatuhan dari karakteristik orang-orang yang berkuasa di dalam suatu organisasi tersebut akan mempengaruhi nilai akhir dari tujuan kebijakan dilaksanakan. kerjasama dan kepahaman akan program yang dilakukan menghasilkan kesuksesan program yang telah diimplementasikan. dinas sosial yang mengurusi dan bertanggung jawab terhadap pelaksanaan program keluarga harapan di daerah Kota Dumai tidak memiliki akses langsung kepada lembaga eksternal yang bersangkutan dengan tegang keluarga harapan karena program ini adalah alasan arahan langsung yang diberikan kepada kementerian dengan undang-undang yang telah disusun dan Proklamasi khusus yang telah disamaratakan se-indonesia. pelaksanaan sesuai dengan perundang-undangan yang berlaku lembaga eksternal Pasti Bertanggung jawab dan bekerja sama langsung dengan Kementerian seperti dalam bentuk hubungan pertahanan dan pengumpulan informasi serta validasi data dengan lembaga riset itu Badan Pusat Statistik Nasional. dalam tingkat daerah sumberdaya masyarakat yang dikerahkan sebagai lembaga eksternal untuk mempengaruhi program cuaca Harapan ini Yaitu dimulai dari tingkat terbawah Rukun Tetangga dan bekerjasama dengan perangkat kesehatan serta Posyandu untuk menyukseskan pelaksanaan program keluarga harapan.

\section{h. Compliance and Responsiveness (Tingkat Kpatuhan dan Adanya Respon dari Pelaksana)}

Tingkat kepatuhan dengan respon dari pelaksana yang diharapkan akan menjadikan pelaksanaan program ini lebih sukses yaitu salah satunya adalah jarimah bantuan program keluarga harapan yakni ke rumah tangga sangat miskin dapat menyesuaikan dirinya dengan alasan yang diterima oleh para pendamping. pentingnya tingkat kepatuhan akan membuat bantuan ini akan lebih terarah dan efektif. 


\section{Faktor penghambat dalam implementasi Program Keluarga Harapan di Kecamatan Dumai Barat} a. Pembinaan dan Sosialisasi yang masing belum merata

Program Keluarga Harapan (PKH) yang diterapkan oleh pemerintah melalui Kementrian Sosial, pada dasarnya program ini bertujuan untuk membantu meningkatkan kualitas pendidikan dan kesehatan. Yang paling penting dalam operasional program ini adalah bahwa masyarakat dapat menyekolahkan anakanaknya serta ibu hamil dan balita dapat memeriksakan kesehatannya sebagaimana tujuan dari program ini. Namun kenyataanya dilapangan penulis melihat bahwa tidak semua masyarakat tahu akan adanya program keluarga harapan ini. Keterlibatan stakeholder dalam penyampaian proram ini menjadi kunci utama dalam kesuksesan program tersebut. Bila dikaitkan dengan yang ada dilapangan sosialisasi hanya dilakukan sampai pada tingkat perangkat saja sedangkan untuk masyarakat sangat kurang atau sangat minim. Pengetahuan masyarakat akan adanya program keluarga harapan Ini hanya ketika masyarakat yang bersangkutan menerima bantuan ini. Hanya masyarakat yang pernah menerima program ini saja yang yang tahu akan keberadaan program keluarga harapan. terdapat aturan-aturan yang membahas tentang komponen-komponen penerima manfaat yaitu salah satunya dengan melihat kondisi rumah dari calon penerima manfaat sebagai tahap penilaian kelayakan penerima. namun setelah dilakukan musyawarah daerah di Pekanbaru yang bahas mengenai program-program dan syarat penerimaan komponen penerima manfaat terdapat beberapa perbedaan kondisi warga di beberapa daerah di kabupaten kota Provinsi Riau. masalah yang terjadi di Kota Dumai bahwa kondisi rumah untuk masyarakat sangat miskin khususnya di Kecamatan Dumai barat memang sedikit berbeda dengan kondisi yang lain karena dari nama-nama yang telah diterima oleh Dinas Sosial Kota Dumai bahwa setelah dilakukan pengecekan beberapa bentuk rumah dari para calon penerima tidak separah dengan deskripsi di peraturan penerima program keluarga harapan. oleh karena itu Salah satu syarat sebagai penerima manfaat yaitu kelayakan rumah di kota Kota Dumai agak dilonggarkan karena berdasarkan penelusuran yang dilakukan oleh peneliti dan pendamping bahwa kondisi keuangan dari keluarga tersebut memang tidak baik namun kondisi rumah yang jika dilihat dari luar dinilai masih cukup bagus. namun berdasarkan wawancara dengan RT keluarga tersebut tetap menerima dan termasuk dalam komponen penerimaan bantuan program keluarga harapan. para peserta musyawarah tersebut menilai bahwa bentuk rumah juga merupakan salah satu nilai dari kearifan lokal di wilayahnya masing-masing karena hal tersebut adalah ciri khas yang menggambarkan tentang wilayah tersebut

\section{b. Sumber daya yang masih kurang maksimal yaitu kurangnya anggaran serta tenaga pekerja yang tidak mencukupi.}

Sumber daya yang harus dipenuhi dalam pelaksanaan sebuah kebijakan merupakan salah satu faktor pendukung dari keberhasilan dan kesejahteraan pelaksana untuk mengerjakan program tersebut karena kualitas hasil kerja akan berpengaruh dengan fasilitas sumber daya manusia serta pendanaan yang cukup agar kebijakan dapat diselesaikan dengan baik hari ini juga menjadi salah satu faktor terpenting program keluarga harapan ini dapat dijalankan. Keluarga penerima manfaat yang tidak dapat hadir dalam pertemuan pertemuan yang telah diatur oleh pendamping Kelurahan untuk memberikan pemantauan serta pengarahan mengenai kelas dan harapan menjadi kendala tersendiri dalam mencapai titik keberhasilan dalam bidang kualitas sumber daya manusia. hal ini menjadikan para pendamping harus mengunjungi langsung kepada penerima manfaat agar bisa mengkonfirmasi secara langsung penyebab hal tersebut terjadi . setelah melakukan penelusuran penelitian dan responden dari pendamping Kelurahan bahwa masih ada keluarga penerima manfaat yang sering pindah alamat dan tidak sesuai dengan domisili yang tercatat di buku pencatatan sipil serta data oleh pendamping kelurahannya. hal ini memang disebabkan oleh kondisi pekerjaan dari rumah tangga sangat miskin tersebut yang berganti-ganti dan juga berpindahpindah karena pekerjaan yang tidak tetap dan kondisi rumah yang masih sewa. bahkan ada keluarga yang sering berpindah rumah sekitar dua hingga tiga kali dalam satu tahun.Terdapat beberapa hambatan yang 
dirasakan oleh pekerja sosial masyarakat dalam mendistribusikan bantuan. keluarga penerima manfaat juga diberikan beberapa fasilitas sebagai menunjang ekonomi mereka yaitu seperti bantuan usaha namun terdapat hambatan yang dirasakan di lapangan yaitu waktu yang sulit diatur dengan para penerima manfaat komunikasi yang kurang baik serta kemampuan administrasi dari pekerja pekerja sosial masyarakat yang melaksanakan program tersebut.

\section{c. Validitas data penerima Program Keluarga Harapan yang masih lemah}

Validitas data pada setiap implementasi kegiatan sangat penting dan hal ini merupakan pengaruh sosial ekonomi pengrajin yang menjadikan penentu bahwa kebijakan agar dapat dilaksanakan dengan baik atau tidak. lingkungan kebijakan juga akan mempengaruhi Bagaimana peraturan tersebut dilaksanakan serta taraf keberhasilan dari program tersebut. lingkungan pelaksanaan program keluarga harapannya khususnya di kecamatan Dumai barat ini dilaksanakan dengan mengutamakan peraturan yang telah ditentukan dan bantuan pemerintah tersebut diusahakan agar bisa terus salurkan dan diterima oleh penerimaan manfaat dengan lancar. Dinas Sosial juga menyelenggarakan program ini dengan mengutamakan bantuan pemerintah dan tenaga tenaga yang disalurkan agar bisa menunjang perekonomian kehidupan para penerima manfaat. kondisi paling parah yang terjadi pada saat ini Hal ini disebabkan dengan adanya penyebaran covid-19 dan menyesuaikan dengan aturan kesehatan yang berlaku. penyesuaian jam kerja dengan tugas yang harus selesai diselesaikan Memang agak kesulitan untuk penyesuaian lainnya. sehingga kami menerima beberapa laporan pada akhir-akhir ini terjadinya keterlambatan penyaluran bantuan kepada penerima manfaat yang penyebabnya antara lain kurangnya jam kerja dengan sistem shift dan penumpukan data yang harus diolah di kantor.

\section{KESIMPULAN}

Berdasarkan uraian hasil penelitian dan pembahasan, dapat ditarik kesimpulan sehubungan dengan permasalahan penelitian bahwa implementasi Program Keluarga Harapan (PKH) Kecamatan Dumai Barat mendapat dukungan dari berbagai pihak kecamatan, desa, dan antusiasme masyarakat menengenai program ini . Meski demikian, ini belum maksimal dan masih banyak kekurangan yang perlu diperbaiki. Hal ini terlihat dari kelompok sasaran yang belum tepat; jumlah pelaksana yang terbatas baik dari segi kuantitas maupun kualitas (skill) sehingga belum bisa dikatakan maksimal. Berdasarkan teori Grindle terdapat faktor penentu kebijakan antara lain :

1. Interest Affected ( Kepentingan yang mempengaruhi ) : program keluarga harapan di Kota Dumai khususnya di Kecamatan Dumai Barat diselenggarakan dari adanya pelaksanaan yang dibantu oleh pendamping Kecamatan akan melakukan validasi data dan kecocokan data yang bekerjasama dengan pendamping Kelurahan selanjutnya pendamping Kelurahan akan menjadi penanggung jawab untuk pengawasan setiap KPM

2. Type of Benefits ( Tipe Manfaat ) :manfaat yang diterima KPM dalam pelaksanaan program keluarga harapan ini yaitu berupa bantuan sosial yang diberikan kepada penerima manfaat serta pendamping lalu pelayanan fasilitas fasilitas pendidikan kesehatan untuk menunjang Kesejahteraan Sosial bagi penerima manfaat, program penunjang ekonomi seperti ada dorongan pendidikan kesehatan dan subsidi energi.

3. Extent of Change Envision (Derajat Perubahan yang Ingin Dicapai) : Adanya keinginan untuk penerima manfaat dalam merubah keadaan hidupnya dengan memanfaatkan peluang memperbaiki keadaan ekonomi mereka melalui bantuan ini, meringankan beberapa kewajiban beban ekonomi seperti dana wajib yang harus dikeluarkan seperti kebutuhan sekolah anak, 
sehingga penghasilan yang didapatkan bisa diarahkan untuk hal lain serta kebutuhan makanan sehari hari.

4. Site of Decision Making (Letak Pengambilan Keputusan) : Dalam mengambil sebuah keputusan haruslah memperhatikan organisasi dengan menyesuaikan struktur serta strategi yang akan dilakukan oleh kebijakan ke depan sesuai dengan tujuan peraturan tersebut dibentuk. terdapat juga beberapa rekomendasi dari bawahan mengenai solusi solusi dari permasalahan yang harus diperbaiki kedepannya yaitu dari Hierarki kebijakan Kementrian, Dinas Sosial, Kecamatan hingga Kelurahan.

5. Resources Committed (Sumber-Sumber Daya yang Digunakan) : sumber daya manusia yaitu petugas pelaksana program PKH sebagai orang yang menjalani implementasi dan mengatur pelaksanaan PKH di Kecamatan Dumai Barat. Mereka diberikan hak dan kewajiban berupa gaji serta diberikan fasilitias penunjang pekerjaan seperti alat-alat kerja . Hal ini adalah komponen pendukung untuk mempermudah proses pekerjaan tersebut.

6. Power, Interest, and Strategy of Actor Involved (Kekuasaan, Kepentingan-Kepentingan, dan Strategi dari Aktor yang Terlibat) :Pengarahan program keluarga harapan untuk kesejahteraan masyarakat telah memberikan tugas tugas kepada pendamping di Kelurahan untuk mengawasi keluarga penerima manfaat serta memberikan edukasi kepada mereka melalui pelatihan dan pertemuan rutin yang materinya telah dipersiapkan sesuai dengan programs penyusunan di kementerian.

7. Institution and Regime Characteristic (Karakteristik lembaga dan rezim yang sedang berkuasa) : pelaksanaan sesuai dengan perundang-undangan yang berlaku lembaga eksternal Pasti Bertanggung jawab dan bekerja sama langsung dengan Kementerian seperti dalam bentuk hubungan pertahanan dan pengumpulan informasi serta validasi data dengan lembaga riset itu Badan Pusat Statistik Nasional.

8. Compliance and Responsiveness (Tingkat Kpatuhan dan Adanya Respon dari Pelaksana) : Bentuk evaluasi yang dilakukan pada pelaksanaan program keluarga harapan secara rutin yaitu Melalui rapat kerja dan musyawarah gabungan antara kelurahan kecamatan dan Kabupaten hal ini merupakan salah satu cara untuk memperbaiki permasalahan-permasalahan serta memberikan solusi yang tepat dan menyesuaikan dengan masalah di daerah masing-masing

Hambatan dari pelaksanaan Program ini yaitu Implementasi Program Keluarga Harapan (PKH) belum optimal.

1. Sumber daya masyarakat yang masih perlu dilakukan penyesuaian jumlahnya antara operator program keluarga harapan dengan keluarga penerima manfaat di tiap kelurahan di Kota Dumai, hal ini dirasa jumlah operator masih kurang dan perlu di tambahkan kembali.

2. Minim anggaran untuk di lokasi penempatan program untuk memperkerjakan operator tersebut.

3. Validasi dan akurasi data yang masih kurang, hal ini juga dikarenakan kurangnya sumber daya manusia sebagai pengolah data dan masih kurangnya tenaga pemantau untuk setiap Keluarga Penerima manfaat di Kota Dumai khususnya Kecamatan Dumai Barat.

\section{SARAN}

Berdasarkan uraian Kesimpulan diatas, dapat direkomendasikan saran saran sebagai berikut :

1. Pentingnya pemerintah Kecamatan Dumai Barat dan jajarannya serta instansi terkait untuk mengoptimalkan implementasi Program Keluarga Harapan sesuai dengan tujuan yang diinginkan dalam rangka meningkatkan kualitas pendidikan dan kesehatan rumah tangga sangat miskin (RTSM). 
2. Perlu adanya penambahan jumlah pendamping PKH untuk sehingga tujuan program ini dapat tercapai.

3. Perlu diadakan sosialisasi yang mendalam dari para pelaksana program keluarga harapan kepada peserta penerima program PKH agar kedepannya dapat berjalan lebih baik.

4. Diharapkan kepada warga masyarakat peserta program keluarga harapan supaya menggunakan bantuaan ini dengan sebaik-baiknya dan jika ada keluhan mengenai keluarga harapan ini segara melaporkan pendamping $\mathrm{PKH}$ untuk dicarikan solusinya.

\section{DAFTAR PUSTAKA}

[1] Ali, Farid dan Andi Syamsu Alam. (2012). Studi Kebijakan Pemerintah. PT Refika Aditama: Bandung.

[2] Abidin, Said Zainal. (2012). Kebijakan Publik. Salemba Humanika: Jakarta.

[3] Agustino, L.(2008). Dasar-Dasar Kebijakan Publik. CV Alfabeta: Bandung .

[4] Agustiano, L. (2020). Dasar-dasar kebijakan publik edisi revisi ke -2 . CV Alfabetha : Bandung

[5] Bungin, Burhan. (2007) . Penelitian Kualitatif. (Edisi Kedua) . Jakarta : Kencana Prenada Media Group .

[6] Dunn, William N. (2003). Pengantar Analisis Kebijakan Publik Edisi Kedua. Gadjah Mada University Press: Yogyakarta.

[7] Grindle, Merilee S. (1980). Politics and Policy Implementation in The Third World, Princnton University Press, New Jersey.

[8] H.B Sutopo. (2002). Pengantar penelitian kualitatif. Universitas sebelas maret press : surakarta .

[9] Modul Diklat PKH. 2013

[10] Nugroho D. Riant. (2003). Kebijakan Publik :Formulasi Implementasi dan Evaluasi. PT. Elex Media Komputindo: Jakarta.

[11] Parson,W.(2005).Public Policy : Pengantar teori dan Praktek Analisis Kebijakan. Prenada Media: Jakarta.

[12] Pasolong, H (2020). Metode Penelitian Administrasi Publik. Alfabetha :Bandung. 